\title{
The Concept of eGovernment: ICT Policy Guidelines for the Policy Makers of Ghana
}

\author{
S. K. Mahama Ewurah \\ College of Public Administration, Huazhong University of Science and Technology, Wuhan, China \\ Email: kandiaewurah@yahoo.com
}

How to cite this paper: Mahama Ewurah, S.K. (2017) The Concept of eGovernment: ICT Policy Guidelines for the Policy Makers of Ghana. Journal of Information Security, 8, 106-124.

https://doi.org/10.4236/jis.2017.82008

Received: March 14, 2017

Accepted: April 27, 2017

Published: April 30, 2017

Copyright $\odot 2017$ by author and Scientific Research Publishing Inc. This work is licensed under the Creative Commons Attribution International (CC BY 4.0).

http://creativecommons.org/licenses/by/4.0/ (c) (i) Open Access

\begin{abstract}
It is obvious that no government or business operation can be done without some kinds of involvement of ICTs in the process. However, research shows that, the policies and implementation of ICTs in delivering public services face several challenges in different countries due to country level peculiarities and cultures. These challenges are socio-technical from the prospective of soft and hard implications of the eGovernment systems. This paper tries to follow the soft or social issues limiting the efforts in designing and implementing ICT policies in Ghana. We identify some of the challenges in respect of the policy makers and back and front office users of ICT systems. This paper has therefore, elaborated the concept of eGovernment within context of the understanding of the lay ICT policy maker and systems users of Ghana. The issues addressed in this article range from development to the sustainability of eGovernment systems, policies and stages that resonate with norms and culture, political and the administrative style of Ghana.
\end{abstract}

\section{Keywords}

ICT Policy Guidelines, eGovernment Stages, Ghana

\section{Introduction}

The role of ICTs in information and knowledge base economy and national development is so pervasive and inevitable force that can't be ignored by any contemporary government [1]. ICTs are seen as liberating technologies, as technological experts see them as inevitable and the existence of advanced computers and the Internet may force such liberating developments upon governments [2] [3] [4] [5] [6]. Thus, ICTs don't necessarily need government's approval for their penetration but citizens' endorsement and patronage is enough for their survival. In the era of ICTs, people want to arrange their own schedules, to engage and 
work for their private activities from a location of their choice and it is common knowledge that ICTs can offer such services or leeway as they reduce cycle times, quicken every process, and drive ineffectiveness out of economies [7].

Like e-business in the private sector, eGovernment evolved in the government sector in response to ICTs euphoria. As part of the many benefits of eGovernment, government agencies are now shifting routine work to consumers/citizens through self-service applications. To do this, governments need to offer a conducive environment by introducing programs and policies for building backup economic, regulatory, and social infrastructure to realize the benefits of the information society. The outreach for the application of ICTs and adoption of eGovernment for nation development is well communicated. For instance, almost all UN member states now have national ICT/eGovernment policies for the realization of UN targets which include connecting learning institutions, provision of access to more than half of the world's population to e-services and ICTs, research centers, libraries, hospitals with ICTs and creating community access points to link villages into the information network [8]. As a result, national governments including Ghana are automating processes and setting up national ICT policies, putting information infrastructure albeit very humble beginnings.

Furthermore, there are visible efforts that are being made at local and central government levels in different underdeveloped countries to adopt eGovernment projects and programmes, which are seen as a right way to make sure there is accountability in handling governmental affairs and performance and efficiency in managing public services [9]. Accordingly, in 2003, Ghana developed Information and Communication Technology for Accelerated Development (ICT4AD) policy aimed to modernize Ghana into an information-rich knowledge based society and Economy through the deployment, development, and exploitation of ICTs throughout the society and economy [10].

Other countries have also formulated similar policies, which are in various stages of implementation and operation [11]. The definitions and implementations face both technical and social challenges as implementers lack the proper knowledge to handle ICTs projects technically and/or have a misconception about the whole concept of eGovernment by resisting such systems socially. The policy maker or public servants of Ghana are not immune from this challenge as eGovernment is in its infancy in Ghana and Africa as a whole. This paper therefore seeks to explain the eGovernment concept to the understanding of the policy maker and/or public servants to rally their support for such projects in the country.

The concepts and findings are built out of comparative studies through literature reviews. The most online database (ScienceDirect.com) for eGovernment and management studies is searched with keys such as eGovernment, Ghana ICT policies and guidelines, and implementation challenges.

\section{The Study Area}

Ghana is located on the West Coast of Africa and formerly known as Gold Coast. It shares boundaries with Burkina Faso, Togo, la Cote d'Ivoire and the 
Gulf of Guinea covering a total land area of 238,500 square kilometers. In July 2013, the population of Ghana was estimated to be 25,199,609 from over one hundred ethnic groups with over 25 ethnic languages.

The country was colonized by the British so English, however, is the official language, one of the legacies of British colonial rule. Both political and administrative systems are in line with the western style. Ghana became the first country in sub-Saharan Africa to gain independence in 1957 led by Dr. Kwame Nkrumah as the nation's founding president.

However, he was overthrown in 1966 coup d'etat. After the first president, Ghana was ruled by military despots amidst democratic rules, curtailed by the military takeovers and returned to the current democratic rule since 1992 to date and now seen as the most thriving democracy on the continent by international democratic community.

The economy is monopolized by agriculture with 40 percent of the country work force and contributes $31.8 \%$ and $12.8 \%$ to the country's GDP, which stood at 37.54 billion US dollars in 2015 in 2009 and 2015 respectively. Ghana is a major cocoa producer in the world. Some commodities such as gold and lumber are major exports with a recent discovery of oil in 2007 in the county. Finally, the country boasts of a vibrant telecommunications sector, with six cellular phone industry operators and several Internet service providers, good news for eGovernment and technology determinists.

\section{Literature Review}

\subsection{ICTs in Public Management}

The Ghana economy was in decline within a period from 1974 to 1980 and couldn't utilize any ICTs to overcome the constraints at the time [12]. The low productivity was partly attributed to policy failures, heavy hand of bureaucracy, mismanagement, staff redundancy, inefficient state enterprises, and poor infrastructure. The devastating features challenged the capacity of the civil service for implementing any initiative and policies and also affected performance and morale resulting in the low productivity [13]. The country could not do otherwise than go in Economic Recovery Programme (ERP) and the Structural Adjustment Programme (SAP) [14].

The problems of implementing the reforms stemmed partly from the lack of leadership and lack of innovations and technology in the service. These challenges, at that time rekindled the observation of the first president that "it amazes him that up to the present many civil servants do not realize that we are living in a revolutionary era". The country has wasted time serving colonial masters and cannot any archaic snail-pace methods of work that obstruct progress. $\mathrm{He}$ told civil servants to develop a new orientation to enable them to eliminate all elements towards red tapeism and waste [15]. This supposedly marked the beginning of thinking "outside the box" and embracing innovation but it wasn't until in the late 1990's, Ghana government faced problems with the upgrading of its personnel management system and embraced the use of ICTs to automate the 
processing, retrieval and storage of personnel records of its civil service staff [16].

This brought about many decisions to reform the civil service workforce across all government agency and departments for critical administrative reforms through the application of ICTs. The reforms further demanded that the structural adjustment programs should include goals for the civil service to improve their management and reduce labor costs by downsizing government staff in the public-sector workforce through ICTs in order to get loans from the IMF and World Bank. Despite the foregoing efforts, the civil service was still lacking the capacity to implement subsequent reforms due to the failure in the registry system to keep data recordings about the number of staff in the civil service. The data available were riddled with numerous inaccuracies including records of non-existent staff, position and tenure and inaccurate data on employees due to the manual handling of the registry.

The manual system for tracking staff contained a lot of errors and needed some information management tools to correct it. Because of these problems, the workforce reductions as required by funders and donors were not met. Ghana therefore developed its first Human Resource (HR) information systems in the civil service in 1998. The efforts to build the HR system lasted almost four years longer than projected to implement due to both technical and social reasons but finally developed. The data inaccuracies in the manual records still caused problems, as some employees didn't get their salaries for the subsequent months in the new system.

This called for the need to do more software programming and data validation. There were still pockets of data inaccuracies in the electronic records but the country forged ahead to use back-office database systems that promised greater data accountability and accuracy. Now management was able to take right policies and decisions about personnel management using the new HR information system [13]. Although it was a difficult experience, the HR system provided early technological infrastructure to pioneer eGovernment services in the country. Subsequently, after the elections in 2000, the Ministry of Communications and Technology lead Ghana into building telecommunication infrastructure that can bring about eGovernment services in the country.

The earlier initiatives concentrated on refining its existing administrative structures to function as the databases for Ghana as the national clearinghouse for information in consultation with: The Office of the President; Ministry of Finance (MoF), Ministry of Foreign Affairs (MoFA), Ministry of Health $(\mathrm{MoH})$, Ministry of Food and Agriculture, Ministry of Trade and Industry (MoTI), Parliament including Ten Regional Coordinating Councils. This also resulted in the development of ICT4AD policy document in 2003 (this policy document is at the heart of this study and carries its own topic). Also, in 2006, Ghana launched eGhana project in preparation for its eGovernment strategy in the country. The goal of this project is to improve the development of the ICT sector, IT Enabled Services, support local ICT businesses and encourage the development of eGovernment government communications and applications. Among the many ob- 
jectives, the focus is to implement a web portal, create standards to support the interoperability of its computer systems, set up a high-speed network for data sharing, improve the training of government ICT-related employees and improve the security of government databases [17].

Ghana is now struggling with new issues to develop the interest in developing and using ICT/eGovernment services in the country [18]. The use of mobile phones has exploded in Ghana, in using mobile communications in accessing audiovisual content. However, a policy maker remarked that most of the content involves sports, entertainment and rather than addressing the challenges of education, employment and empowerment [19]. There is also growing concern that government must develop an Internet culture in the country to lure people into using services online to promote eGovernment services in the country. To meet this objective, there must be assurance of systems integrity. This calls for some legal reforms to litigate Internet fraud and cyber related issues.

The Communication and Information Directorate of Ghana is refining their systems with strategies to connect together all administrative processes and to increase the performance (e.g. minimizing the down time of computer servers and acquiring equipment) of the systems. This will bring trust in the eGovernment services as the systems become more reliable and trustworthy.

\subsection{Some History of eGovernment}

eGovernment is explained as the use of ICTs in government to improve public services, managerial effectiveness and to promote democratic mechanisms and values including regulatory framework that assists information intensive projects in the knowledge society [20]. In the concept of eGovernment is simply to utilize the World Wide Web and the Internet for information dissemination and eservices to its stakeholders. This is a direct response to the efficient service delivery by private e-business due to technological change [21].

The private sector exploited the Internet on large scale than governments though the Internet begun in the United States as a government program [22] [23]. It is logic that governments should lead in e-services, but the private sector did. Osborne and Gaebler (1992) [24] and Kamarck (2000) [25] argued that earlier bureaucracies failed to deliver in the century because of the changing knowledge-intensive society of the 1990s, creating a demand for reforms in governmental processes simply by showing the distance in performance between the public sector and the private sector.

In the United States in the 1950s, banking was almost same as an interaction with government official [26]. But through ICTs, the information economy facilitates the private sector to cater for the customer timely and deliver service through ATMs at any time of the day while the governmental sector is weighed down by both heavy bureaucracy and manual handling of service delivery [27]. However, this triggered governments to begin to see the liberating power of the new technologies of the word that can reduce the costs of public services and also help to rebuild relationships between citizens and their governments [28]. In 
addition, the concept of eGovernment goes beyond government agencies where they engage just in transferring money by issuing plastic, 'smart' benefit cards with a chip to providing Citizens with public assistance benefits, receive veterans services, to enroll in training programs through these cards. These smart cards contain information about citizens' financial positions and tracking their benefit accounts to reduce fraud [29]. This makes eGovernment looks fairer, more secure, more responsive to citizens, and more efficient than the paper based systems [30].

At this point, after realizing the capabilities of ICTs, many governments started crafting policies for their use. In 1990, for instance, the United Kingdom proposed a policy, that by 2008 all public services should be able to be delivered electronically [31]. Many government administrations have distributed intranets and Internet with a personal computer on the desk of all public servants and greater use of the Internet now become possible. Many eGovernment projects are still underdeveloped but there is an international trend towards their implementation, though eGovernment policies are designed according to local conditions and cultures [32].

There are many initiatives of eGovernment currently (the e-Europe Action Plan, 2002; Portugal's Society of Information 2000-2006 programme, Australia's Government Online strategy and the Netherlands Electronic Government Action Plan) [33]. Ghana developed its ICT policy document (ICT4AD) in 2003 [34] and is no exception in the ICTs crusade. On the downside, there are several failure reports of ICT policies and projects [35]. Table 1 shows some of the reasons for the failures.

\section{Evolutionary Stages of eGovernment}

The concept of eGovernment varied along socio-cultural and administrative regimes. In this respect, the developments of eGovernment don't follow a linear progression. Government's adaption and adoption of technologies determine the pattern of many eGovernment policies and evolution. Many considerations play vital roles in the evolutionary process. These include issues about the governing system, politics, administrative style, available technology, education and cultures, and economic power.

The processes involved may determine the pattern. Bellamy and Taylor (1998) [28] have categorized these processes into three stages: the first stage is "automation" and managerialism to reduce the costs of existing manual processes; the second stage is "informatization" as a shift from computerization to emphasis on the information; and the final stage is that of "transformation" defined as applying business process reengineering to totally restructure across organizational shields, to share data. More of the process classification can be seen in the five stages identified by the UN (2008) [36] for the purpose of benchmarking its member state eGovernment development as described below.

1) Emerging Stage

The basic unit of these processes is creating a webpage to announce govern- 
Table 1. ICT/eGovernment project failure reasons.

\begin{tabular}{lll}
\hline Reason & Comment & Citation \\
\hline & & Pinto and Mantel (1990), Heeks (2001, \\
& 2003), Dada (2006), Gil-Garcia and Pardo \\
Concern hard-soft gaps & $(2005)$, Ebrahim and Irani (2005), \\
(between technology and social context); & Almarabeh and AbuAli (2010), Sarantis et \\
Design-reality & private-public gaps & al. (2011), Goldfinch (2007), Gauld (2007), \\
gaps & (differences between the public and the & Nielsen and Pedersen (2014), Luk (2009), \\
& private sector); and country context gaps & Guha and Chakrabarti (2014), Ojiako et al. \\
& (variances between counties) & (2008), Scholl (2003), Kamal, Weerakkody, \\
& & and Irani (2011) and Tan et al. (2005)
\end{tabular}

Missing or ambiguous business

Missing focus focus and/or unclear objectives or absence of need

Project scope definition, change

Content issue management, shifting requirements and or/technical complexity

Skill issues

Project unaligned team and/or lack of skills

Unrealistic schedule and/or reactive

Execution issues planning; and misinformation with regard to massive and unaccounted cost overruns, benefit shortfalls, and waste legal framework, policy and standards.

Regulatory Unpredictability of changes in the issues regulatory framework, failure due to legal disputes, implications of legal certainty in the digital realm

External

factors

Outside the project organization

Missing user satisfaction

Projects do not succeed in meeting users' expectations and project products Gozlu (2008), Luk (2009), Tan et al (2005) are not of public interest and use

Pinto and Mantel (1990), Imamoglou and and Janssen et al., (2013), (2015)
Pinto and Mantel (1990), McKinsey and Company (2012), Sarantis et al. (2011), Imamoglou and Gozlu (2008), Kappelman et al. (2006), Scholl (2003), Kamal et al. (2011), Tan et al. (2005), Boehm (2000) and Nelson, (2007)

Pinto and Mantel (1990), McKinsey and Company (2012), Gil-Garcia and Pardo (2005), Almarabeh and AbuAli (2010), Sarantis et al. (2011), Verner et al. (2008), Hidding and Nicholas (2009), Gauld (2007), Kappelman et al. (2006), Luk (2009), Ojiako et al. (2008), Scholl (2003), Kamal et al. (2011), Tan et al. (2005), Boehm (2000), Aikins (2012), Fairley and Willshire (2003) and Loukis and Charalabidis (2011)

Pinto and Mantel (1990), McKinsey and Company (2012), Gil-Garcia and Pardo (2005), Ebrahim and Irani (2005), Gichoya (2005), Verner et al. (2008) and Luk (2009)

Pinto and Mantel (1990), McKinsey and Company (2012), Verner et al. (2008), Imamoglou and Gozlu (2008), Hidding and Nicholas (2009), Gauld (2007), Kappelman et al. (2006), Luk (2009), Ojiako et al. (2008), Scholl (2003), Kamal et al. (2011), Tan et al. (2005), Boehm (2000), Pardo and Scholl (2002), Fairley and Willshire (2003) and Loukis and Charalabidis (2011)

Gil-Garcia and Pardo (2005), Luk (2009) and Paulin (2014, 2015)

Goldfinch (2007), Nielsen and Pedersen (2014), Luk (2009), Guha and Chakrabarti (2014) and Tan et al. (2005)

E-government project failure factors 


\section{Continued}

Organizational Organization structure and relations
power

Politics

Education

Government and top-level leaders' commitment, and appropriate political support

Appropriate skills for project operation and acceptance, as well as execution of training activities

Underestimate of timeline; weak Project definitions of requirements and management scope; inefficient risk analysis and issues management; unsuccessful monitoring and measurement

Ambiguous

business needs Project's objectives are not and unclear clear or justified for their necessity vision

Security and privacy

Project products do not secure

Finance and

operational

costs transactions and sensitive information.

Deliverables' operation and maintenance costs were underestimated and not secured

ICT and system development process
Problems with regard to infrastructure, data, compatibility, information management
Warne and Hart (1996), Warne (1997), Ebrahim and Irani, (2005), Gauld (2007), Nielsen and Pedersen (2014), Scholl (2003), Boehm (2000), Janssen and Klievink (2012) and Janssen et al., (2013), (2015)

Warne and Hart (1996), Warne (1997), Almarabeh and AbuAli (2010), Gauld (2007), Nielsen and Pedersen (2014), Tan et al. (2005), Lyytinen and Robey (1999), Verner et al. (2008) and Boehm (2000)

Pinto and Mantel (1990), Lyytinen and Robey (1999), Gichoya (2005), Almarabeh and AbuAli (2010), Goldfinch (2007), Verner et al. (2008), Scholl (2003) and Boehm (2000)

Pinto and Mantel (1990), Warne and Hart (1996), Warne (1997), Pardo and Scholl (2002), Yeo (2002), Gil-Garcia and Pardo (2005), Ebrahim and Irani (2005), Gichoya (2005), Almarabeh and AbuAli (2010), Sarantis et al. (2011), Goldfinch (2007), Verner et al. (2008), Hidding and Nicholas (2009), Gauld (2007), Nielsen and Pedersen (2014), Kappelman et al. (2006), Luk (2009), Ojiako et al. (2008), Scholl (2003), Kamal et al. (2011), Tan et al. (2005), Boehm (2000) and Aikins (2012)

Pinto and Mantel (1990), Warne and Hart (1996), Warne (1997), Yeo (2002),

Gil-Garcia and Pardo (2005), Sarantis et al. (2011), Kappelman et al. (2006), Guha and Chakrabarti (2014), Scholl (2003), Kamal et al. (2011), Boehm (2000) and Nelson (2007)

Ebrahim and Irani (2005), Almarabeh and AbuAli (2010) and Scholl (2003) Ebrahim and Irani (2005), Gichoya (2005), Almarabeh and AbuAli (2010) and Guha and Chakrabarti (2014)

Pinto and Mantel (1990), Warne and Hart (1996), Warne (1997), Ebrahim and Irani, 2005; Gichoya (2005), Almarabeh and AbuAli (2010), Sarantis et al. (2011), Goldfinch (2007), Hidding and Nicholas (2009), Luk (2009), Guha and Chakrabarti (2014), Scholl (2003), Kamal et al. (2011), Tan et al. (2005), Nelson (2007), Janssen and Klievink (2012) and Janssen et al., (2013), (2015)

ment or organization web presence. These webpages are only for the purpose of advertising government brand name and activities albeit not interactive but for informational purpose alone. At times, this information is limited, according to recent research [37]. 
This stage marks the interest and will of government going online. Organizational logos and regulations including their services are flooded on the webpages at the emerging stage. The typical department and government home pages at this stage have usually a photo of the head if the head is an elected official and a description of the department. The web presence is also beneficial because it will improve citizens' convenience and reduce the burden on citizens and frontline employees use this information to study the specifics of procedures and policies find out where to go for post-service support and government services.

According to [36] about 193 of its member states have announced their presence online. Many countries especially from Africa including Ghana remain in the emerging stage for long due to socio-technical and political reasons. Few countries with advanced ICT infrastructures and human resources also find it difficult to move to the higher stages due to lack of transparent institutions, and robust data protection. The communication at this stage is one way from governments to citizens/clients.

2) Enhanced Stage

The enhanced stage is an incremental enhanced and have common characteristic of government webpages of the emerging stage. However the information still doesn't meet the qualities of good information-accuracy and timeliness because they are not updated for years. All government departments are victims of this allegation in the country. Citizens and other clients prefer to contact government agencies in person for their information needs at this stage because they are dissatisfied by the outdated websites and webpages.

This could be partly attributed to the fact that there is no clear ownership of the roles to constantly update these systems. The fault is unambiguous and the blame has many sources ranging from inadequate manpower to political issues as mention earlier. The information systems may look technical to civil servants because they may be proper consulted and so end up considering such projects as "their project and not our project" referring to the IT experts as people who own the project.

To solve such oversight, governments to invest heavily in skills development programs and designing web sites that are user friendly to enhance information quality. However, the process of communication is still one way as in emerging stage.

3) Interactive Stage

The interactive stage marks government's full preparation to deliver as much as possible services that can be handled and delivered electronically. It offers opportunity for citizens to download organization forms and access their databases as well. This stage may change the way people interact with their government as processes and workflows are mechanized and handled digitally.

Users can e-mail officials, interact and download forms through the web and make requests and appointments. There is a two-way communications where citizens interact with government agencies with mobile phones and other handheld communication devices connected to Internet. This stage contains web sites 
with interactive forms and e-mail contact that generate informational responses.

4) Transaction Stage

This stage provides a direct link to agency services, available 24/7. The transaction sites enhance efficiency by making government processes faster, simpler and cheaper. The real time activities provided by this require government responsiveness and proper regulation for online activities. Electronic transactions give a bright hope for better efficiency for both the agency and the customer than simply cataloguing information or data.

However, privacy and trust issues are great concern and contribute to the success of the eGovernment project. Citizens do a lot of electronic payment for services online and any inadequate security measures can easily erode people appetite for using the electronic channel. Financial institutions in collaboration with governments have to establish tight regimes to govern the provision of digital certificates for Internet transactions in order to win citizens confidence to participate in online transactions.

Cases of online fraud pertaining to contractual crimes, offering jobs, credit card crimes and advanced fee fraud have been fairly documented [38].

5) The Connected Stage

The connected stage denotes total integration of separate systems at different functions (horizontal) and levels (vertical) of services. Both organizational structure and power relation is affected the emerging trends which change public management both upside down and inside out. Public management in the past is substituted by an external focus, as the usual top-down direction of the field is substituted by a system of shared leadership and citizenship management.

There is total integration of services across administrative boundaries through application of e-functions across departmental borders. The benefits of eGovernment are visible here than the previous stages as portals provide one stop shopping shops for all possible online eGovernment services. Portals bring government departments and agencies together electronically proving both intra and interconnections vertically and horizontally for easy services delivery.

It eliminates data burdens that citizens suffer through multiple submission of one's personal data to be stored in different databases in departments and agencies. For instance, in Ghana, people need to give the same data in almost all government when once data has been collected could be shared to avoid both data and administrative burden on citizens and officials respectively.

However, this stage needs great recourses service for development and maintenance of the system. This may weigh much on national budgets and thereby crowd out poor countries from reaching this point of eGovernment development.

6) Other Stages of eGovernment

There are some other eGovernment stages recommended by researchers and practitioners that can help in the designing eGovernment systems worldwide. We have seen that different countries and organisations have different taste for ICTs application. Information systems evolve with respect to such differences 
and different forms and patterns are seen all over in addition to those discussed previously.

Table 2 shows some patterns by researchers who think the development of eGovernment is dynamic and have different stages [39].

\section{Stakeholders/Relationships in eGovernment}

A governmental portal interacts with various kinds of people and these stakeholders are classified as clusters that have common interest contingent on the kind of interaction between them and governments. A stakeholder is any entity (individual, group, or firm) that is affected by the organization's management decision [40].

There is a wide range of activities and actors in an information system especially eGovernment and four distinct relationships can be identified. Sometimes eGovernment projects are grouped according to these relationships: G2G (Government to Government), G2C (Government to Citizen), G2B (Government to Business), and G2E (Government to Employee). G2E is not talked about here as a substantive matter because it is seen by some observers as an intra-agency activity and forms an integral part of G2G.

Many relationships can be derived but these are the most recognized in the eGovernment research so far. Governments adapt these relationships based on their priority and other factors including socioeconomic and technological standings. However, G2C is mostly considered because governments prioritize their citizens over other things. A brief description on the three main relationships (G2G, G2B and G2C) is done below.

\subsection{Government-to-Government (G2G)}

The G2G means the intra and inter-departmental exchanges at all levels of gov-

Table 2. eGovernment stages by authors.

\begin{tabular}{|c|c|c|c|c|c|c|}
\hline Author & Stages & First & Second & Third & Fourth & Fifth \\
\hline $\begin{array}{l}\text { Gartner, } \\
2000\end{array}$ & 4 & $\begin{array}{c}\text { Web } \\
\text { presence }\end{array}$ & Interaction & Transaction & Transformation & \\
\hline $\begin{array}{c}\text { UN, } \\
200-2008\end{array}$ & 4 & $\begin{array}{l}\text { Emerging } \\
\text { presence }\end{array}$ & Enhanced & Interactive & Connected & \\
\hline $\begin{array}{l}\text { World Bank, } \\
2002\end{array}$ & 3 & Publish & Interact & Transact & & \\
\hline $\begin{array}{l}\text { Accenture, } \\
2003\end{array}$ & 5 & $\begin{array}{l}\text { Online } \\
\text { presence }\end{array}$ & $\begin{array}{c}\text { Basic } \\
\text { capability }\end{array}$ & $\begin{array}{c}\text { Service } \\
\text { availability }\end{array}$ & Mature delivery & $\begin{array}{c}\text { Service } \\
\text { transformation }\end{array}$ \\
\hline $\begin{array}{l}\text { Reddick, } \\
2004\end{array}$ & 2 & Cataloguing & Transaction & & & \\
\hline $\begin{array}{l}\text { Siau \& Long, } \\
\quad 2005\end{array}$ & 5 & $\begin{array}{c}\text { Web } \\
\text { presence }\end{array}$ & Interaction & Transaction & Transformation & E-democracy \\
\hline \multicolumn{7}{|l|}{ Anderson \& } \\
\hline $\begin{array}{l}\text { Henrikson, } \\
2006\end{array}$ & 4 & Cultivation & Extension & Maturity & Revolution & \\
\hline $\begin{array}{l}\text { Mausavi, } \\
2008\end{array}$ & 5 & Cataloguing & Interaction & Communication & Transaction & Integration \\
\hline Lee, 2010 & 5 & Presenting & Assimilating & Reforming & Morphing & E-governance \\
\hline
\end{tabular}


ernment and forms the backbone of eGovernment. This is where government agencies update internal procedures and systems before electronic transactions with businesses and citizens [41]. G2G mostly involves back office operations i.e. sharing data and conducting electronic exchanges between themselves.

Also, regulations and laws that are backing the implementation of eGovernment initiatives fall within this category. State and local governments implement G2G due to their relative proximity, geographically and politically, to citizens. G2G generally deals with other parts of the same government and other governments that exchange information electronically.

\subsection{Government-to-Business (G2B)}

Governments can't do without businesses and vice versa. The policy makers aim at cost cutting and more efficient procurement through ICT means to implement functions, such as sales and procurement in the business world. This leaves governments no choice than embracing such G2B.

Public organizations can best handle processes in procurement systems with G2B interactions with business. Many governments have made significant cost reductions and increase savings e.g. US Department of Agriculture reduced costs for purchase orders from $\$ 77$ to $\$ 32$ per order [42]. Many G2B projects have the potential to improve and reorganize the consistency of personnel-intensive tasks, such as employee benefit changes or processing license renewals.

Reverse auction is common G2B interaction with businesses and individuals to bid in real time against each other to win a contract in government. Reverse auctions has become a frequent means used for purchasing products that are easily evaluated for quality and standardized such as office supplies or off-theshelf technology components in many governments. The decentralized procurement system in G2B relationship saves lead-time in product ordering and delivery and allows agencies to monitor over their own projects [43].

\subsection{Government-to-Citizen (G2C)}

The basic goal of eGovernment is citizen participation in government process by serving them with the best possible means through the magic wand of ICTs and the World Wide Web. This is because citizens have better experience in terms of service quality and delivery from the private sector and become impatient for government long queues for services.

They want to invest their time in more and better things and cannot waste such time standing in lines and enduring bureaucratic nag at government offices. G2C initiatives facilitate also increase citizen participation in government by generating more opportunities that overcome possible geographic and time barriers. People are connecting others electronically who may not physically come into contact with them. These initiatives include renewing licenses and paying taxes are carried out with easiness and less time through G2C.

Some of these initiatives are one-stop shopping site with a variety of tasks, especially those that involve multiple agencies, which doesn't require users to in- 
itiate contacts with each agency individually [44]. Customer resource management techniques are used to foster a good relationship with citizens by making better use of information resources through data mining techniques.

People are motivated to use some of these systems because of low fees for online transactions. For instance, an on-line license renewal in Arizona costs \$1.60 per transaction compared to $\$ 6.60$ manually [45]. These systems are linked with life events and citizen needs to cater for those accustomed to using e-services in their lives [46].

\section{4. eGovernment Systems Development and Challenges}

The benefits of eGovernment and ICTs are obvious as we see in the preceding sections but the difficulty is in their development. It recorded that number of these projects fail though there is very limited data on eGovernment failures [11] [35]. Many fingers point at poor planning but ICTs sometimes become part of problem in our organisations leading to their failures.

Implementing a system without enough preparations may produce an eGovernment service unpalatable to the user and this can cause the system to fail ultimately [47]. Most governments begin to implement eGovernment projects without strategic plans to cover the socio-technical or hard and soft factors [35]. The failure with big public sector computer projects has invoked much research interest on this subject and many factors are on the tables including those listed in Table 3 [48].

Africa records more of these failures because there is less or no professionalism in planning systems or developing methods that will match the information requirements of users.

In addition, some organizations use information systems development methodologies and practices specifically designed for developed countries and they cannot be fit the local realities of Africa. African governments therefore need to use ICT system development practices that are not universal but can be adjusted

Table 3. eGovernment failure factors.

\begin{tabular}{cc}
\hline Number & Failure factor(s) \\
\hline 1 & Drivers of ICT project failures \\
2 & Systems delivered late \\
3 & Creeping scope \\
4 & Software not reliable and robust \\
5 & Lack of integration and effective interface with legacy systems \\
6 & Escalating costs \\
7 & Lack of consultation with users or stakeholders \\
8 & Data integrity and confidentiality issues \\
9 & Poor knowledge of the system and lack of suitable training \\
10 &
\end{tabular}


to suit local socioeconomic and organizational situation [49]. A homegrown approach in planning these systems is required in some situations to avert some of the failures. The benefit of designing systems locally is that it will enable the development team to carefully gather and analyzes detailed information.

They will ask questions of: how data flows in the system, what works and what does not how the government service functions, how humans communicate with the business data and processes, and what the users wish would happen to determine the design-reality gap. In this way, unplanned change is not considered as disruptions but as opportunities to increase the project result [50]. There can be upright rejection of systems by both government officials and end users e.g. workers and women food suppliers agitations at the idea of paying their salaries and contract monies respectively through e-zwitch system in the country.

The downside of this approach is that it is costly and time-consuming because the designers need to define all of the terms of a system before it is launched. Additionally, people in offices don't readily know what they want before the system is built [51]. In addition to paying attention to the failure factors in Table 3 and the principles in Table 4 [52] can help guide us in designing and managing our eGovernment systems.

\section{ICT/eGovernment Policy Guidelines}

There is no doubt that ICTs and their applications have profound effects on economic development in all countries. As we see in the previous sections, their contributions to economic growth are both quantifiable and justifiable. This section highlights the policy issues that help nations to draft policies to unleash benefits from the ICT and information age. The main focus of this section is the policies for promoting ICT usage in general. ICT Policies must cover not only its management and regulation, but also the wider impact on economy, society, and governance [53].

To realize the full potential of ICT, governments must develop coherent, effective policies that can match technological development trends. Such trends

Table 4. Principles for the management of government IT projects.

\begin{tabular}{|c|c|}
\hline 1 & Key decisions about IT systems are business decisions not technical ones \\
\hline 2 & The commitment of senior management is essential \\
\hline 3 & Identifying end users and their needs is critical to the success of a project \\
\hline 4 & $\begin{array}{l}\text { Scale and complexity can easily lead to failure-consider breaking } \\
\text { a project down into manageable sub-components }\end{array}$ \\
\hline 5 & Management and oversight of a project by skilled and knowledgeable managers is essential \\
\hline 6 & $\begin{array}{l}\text { Project managers have to be imaginative and skilled in risk control as } \\
\text { well as in project management }\end{array}$ \\
\hline 7 & A high degree of professionalism is required in the definition, negotiation and management \\
\hline 8 & Adequate training is essential for both system users and system operators \\
\hline 9 & Contingency plans must be in place and they must provide adequate service levels \\
\hline 10 & A post-implementation review of the project is essential for monitoring \\
\hline
\end{tabular}


typically outwit policies to anticipate their effect, but governments should try to make progress in establishing such frameworks.

The frameworks and regulations are required to address complex challenges that emerge from the development of technology into all facets of society. A comprehensive ICT policy framework can be designed along seven functional ways [54]. These include: (1), connectivity and access; (2), usage; (3), legal and regulatory framework; (4), production and trade; (5) skills and human resources; (6), cyber security and (7), new applications. Table 5 summarizes the key priorities in each dimension of these policy frameworks.

Table 5. The dimensions of ICT policy framework.

\begin{tabular}{|c|c|}
\hline Dimension & Focused areas for promotion, upgrading, and progress monitoring \\
\hline \multirow{3}{*}{$\begin{array}{c}\text { ICT } \\
\text { connectivity } \\
\text { and access }\end{array}$} & Broadband connectivity \\
\hline & Mobile phone coverage \\
\hline & Cost and quality competition among ICT products and services providers \\
\hline \multirow{4}{*}{ ICT usage } & Use by individual; use by business; and use by government \\
\hline & Incentives to promote ICT usage by the poor, rural communities, and SMEs \\
\hline & Telecommunications regulation \\
\hline & Spectrum frequency allocation \\
\hline \multirow{5}{*}{$\begin{array}{l}\text { ICT legal and } \\
\text { regulatory } \\
\text { framework }\end{array}$} & E-commerce laws (digital signatures, intellectual property laws, e-payment) \\
\hline & Cyber security laws and regulations \\
\hline & ICT trade tariff and regulations \\
\hline & Access to data and cross-border data transfer \\
\hline & Investment regulations \\
\hline \multirow{5}{*}{$\begin{array}{c}\text { ICT } \\
\text { production and } \\
\text { trade }\end{array}$} & ICT-enabled services and ICT content provision \\
\hline & SMEs in the ICT sector (financing, investment, and capacity building) \\
\hline & Innovation and $\mathrm{R} \& \mathrm{D}$ in the ICT sector \\
\hline & e-market places \\
\hline & $\begin{array}{l}\text { Special industrial parks/zones/villages for ICT sector development } \\
\text { (such as software, high-tech, call centers) }\end{array}$ \\
\hline \multirow{4}{*}{$\begin{array}{l}\text { ICT skills and } \\
\text { human } \\
\text { resources }\end{array}$} & ICT skills in primary and secondary schools \\
\hline & ICT graduates and programs at universities and vocational schools \\
\hline & Training projects to enhance the ICT workforce \\
\hline & Incentives for private sector companies to organize/support ICT capacity building \\
\hline \multirow{3}{*}{ Cyber security } & Minimization of vulnerability to cyber-attacks \\
\hline & National cyber security exercise programs \\
\hline & Emergency response to cyber-attack plans \\
\hline \multirow{3}{*}{$\begin{array}{l}\text { New ICT } \\
\text { applications }\end{array}$} & Smart city development \\
\hline & Big data analysis \\
\hline & Internet of things \\
\hline
\end{tabular}

Sources: [55]. 


\section{Recommendations and Conclusions}

Policy makers should cease the opportunity brought by globalization and the ICT diffusion because it fosters the exchange of creative ideas and knowledge across oceans and borders facilitated by ICT in the increasingly connected information economy. For instance, communication applications and programs (such as WhatsApp, Wechat, QQ, and Skype applications) support instantaneous communication and should be applied in government administration as in social media where these applications heavily are embraced by both politicians and citizens.

The main network infrastructure to boost such applications should be constructed to leverage the growth of connected society and industries in the country. In addition, now that the costs of ICT have momentarily fallen to low levels; effort for ICT use should become a key priority to government and other development partners.

A strategic priority should be about reducing the cost of ICT use, as it will increase the benefits that individuals and businesses get from their investment in ICT applications. As such, the policy impression is that resources should be channeled more to producing benefits of ICT use than to subsidizations for IT cost reduction (such as tax waivers for ICT products).

Another strategic priority should be e-business applications and Internet enabled services. Finally, government should take a pioneering role in using ICT to improve effectiveness and efficiency, especially in G2C and G2B relationships with citizens and businesses respectively by digitizing government services through eGovernment programs. The savings through effective governance generated by eGovernment projects can generate fiscal freedom to reinvest programs that boost the benefits of ICT to individuals and businesses.

With reference to the above recommendations, we conclude by saying the following: first, the advent of ICT has inevitably restructured the way; processes are operated and therefore, policy makers must make right responses in the manner; ICT reforms are formulated to support and manage new types of government practices albeit within local content. For instance, ICTs have affected interpersonal connectivity that has greater implications for organizations, society, public welfare and collective action.

Government must match along these trends to remain internationally competitive; second, the technology underpinning ICT in the country from developed countries, government should where necessary re-make these technologies in local content to uniquely benefit the local people.

Government should also support and recognize these trends including small ventures that often rely on technology for their businesses and four, NITA should be proactive in enhancing the coordination among all sectors to ensure uniform digital integration and adoption of the latest ICTs such as Internet of Things and Industry 4.0 to make the ICT more beneficial.

\section{References}

[1] United Nations (2012) Global E-Government Survey 2012: E-Government for the 
People. UN Department of Economic and Social Affairs, New York.

[2] Scholl, S.J. (2003) E-Government: A Special Case of Ict-Enabled Business Process Change. Proceedings of the 36th IEEE Hawaii International Conference on System Sciences, Big Island, 6-9 January 2003, 12. https://doi.org/10.1109/hicss.2003.1174309

[3] Andersen, K.V. and Henriksen, H.Z. (2006) E-Government Maturity Models: Extension of the Layne and Lee Model. Government Information Quarterly, 23, 236248.

[4] Garson, G.D. (2004) The Promise of Digital Government. In: Pavlichev, A. and Garson, G.D., Eds., Digital Government: Principles and Best Practices, IDEA Group Publishing, Hershey. https://doi.org/10.4018/978-1-59140-122-3.ch001

[5] Anthopoulos, L. and Fitsilis, P. (2014) Trends in E-Strategic Management: How Do Governments Transform Their Policies? International Journal of Public Administration in the Digital Age, 1, 15-38. https://doi.org/10.4018/ijpada.2014010102

[6] Layne, K. and Lee, J. (2001) Developing Fully Functional E-Government: A Four Stage Model. Government Information Quarterly, 18, 122-136.

[7] Henry, C. and Lucas, J. (2008) Inside the Future: Surviving the Technology Revolution. Praeger Publishers, Westport.

[8] United Nations (2014) Global E-Government Survey 2014: E-Government for the Future We Want. UN Department of Economic and Social Affairs, New York.

[9] Rodríguez Domínguez, L., García Sánchez, I.M. and Gallego Álvarez, I. (2011) Determining Factors of E-Government Development: A Worldwide National Approach. International Public Management Journal, 14, 218-248. https://doi.org/10.1080/10967494.2011.597152

[10] Ministry of Communication (2009) Annual for Information and Communication Technology. Accra.

[11] United Nations (2003) World Public Sector Report 2003: E-Government at the Crossroads. United Nations, New York.

[12] Rothchild, D. (1991) Ghana: The Political Economy of Recovery. Lynne Rienner, Boulder.

[13] Ayee, J.R.A. (1991) Civil Service Reform under the Provisional National Defence Council. Journal of Management Studies, 7, 1-12.

[14] Nkrumah, S.A. (1992) Aspects of Administrative Reforms in Ghana under the PNDC Government. University of Ghana, Ghana.

[15] Nkrumah, K. (1962) Statement at the Seminar for Senior Civil Servants at Winneba. The Government Printer, GP/1384/2,500/4/61-62.

[16] Cain, P. (2001) Automating Personnel Records for Improved Management of Human Resources. In: Heeks, R.B., Ed., Reinventing Government in the Information Age, Routledge, London, 135-155.

[17] World Bank (2012) Governments Can Save Up to 75\% with Electronic Payment Program. Washington DC.

[18] ITU (2009) State of ICT Statistics Collection and Dissemination in Ghana. 7 th World Telecommunication/ICT Indicators Meeting, Cairo, 3-5 March 2009.

[19] Perrin, A. (2015) Social Media Use 2005e2015. Pew Research Center. http://www.pewinternet.org/2015/10/08/social-networking-use-2005-2015/

[20] Gil-Garcia, J. and Luna-Reyes, L. (2003) Towards a Definition of Electronic Government: A Comparative Review. Techno-Legal Aspects of the Information Society and the New Economy: An Overview. Formatex, Badajoz. 
[21] OECD (1998) Information Technology as an Instrument of Public Management Reform: A Study of Five OECD Countries. OECD, Paris.

[22] Palfrey, J. and Gasser, U. (2008) Born Digital: Understanding the First Generation of Digital Natives. Basic Books, New York.

[23] Clinton, W.J. (1993) United States Advisory Council on the National Information Infrastructure. Executive Order 12864, Federal Register, 58. www.archives.gov/federal-register/executive-orders/pdf/12864.pdf

[24] Osborne, D. and Gaebler, T. (1992) Reinventing Government: How the Entrepreneurial Spirit Is Transforming the Public Sector. Addison-Wesley, Reading.

[25] Kamarck, E.C. (2000) Globalization and Public Administration Reform. In: Nye, J.S. and Donahue, J.D., Eds., Governance in a Globalizing World, Brookings Institution Press, Washington DC.

[26] Schwanen, T. and Kwan, M.P. (2008) The Internet, Mobile Phone and Space-Time Constraints. Geoforum, 39, 1362-1377.

[27] Weerakkody, V., El-Haddadeh, R. and Al-Shafi, S. (2011) Exploring the Complexities of E-Government Implementation and Diffusion in a Developing Country: Some Lessons from the State of Qatar. Journal of Enterprise Information Management, 24, 172-196. https://doi.org/10.1108/17410391111106293

[28] Bellamy, C. and Taylor, J. (1998) Governing in the Information Age. Open University Press, Buckingham.

[29] Zhang, J., Cresswell, A.M. and Thompson, F. (2002) Participants' Expectations and the Success of Knowledge Networking in the Public Sector. Proceedings of the 8 th Americas Conference on Information Systems, Dallas, 9-11 August 2002, 597-604.

[30] Gore, A. (1993) The Gore Report on Reinventing Government: Creating a Government That Works Better and Costs Less. Report of the National Performance Review, Times Books, New York.

[31] Prins, C. (2001) Electronic Government: Variations on a Concept. In: Prins, J.E.J., Ed., Designing E-Government. On the Crossroads of Technological Innovation and Institutional Change, Kluwer Law International, The Hague.

[32] Von Hippel, E. (2005) Democratizing Innovation. MIT Press, Cambridge.

[33] Accenture (2001) E-Government Leadership Rhetoric vs. Reality Closing the Gap. Accenture, Tokyo.

[34] ICT4AD Policy (2003) The Republic of Ghana. http://www.moc.gov.gh/moc/PDFs/Ghana_ICT4AD_Policy.pdf7

[35] Heeks, R. (2004) E-Government as a Carrier of Context. Sage Publications, London.

[36] United Nations (2008) UN E-Government Survey 2008: From E-Government to Connected Government. UNPAN, United Nations, New York.

[37] West, D.M. (2000) Assessing E-Government: The Internet, Democracy, and Service Delivery by State and Federal Government. The Genesis Institute, Spokane. http://www.insidepolitics.org/egovtreport00.html\&

[38] Magele, T. (2005) E-Security in South Africa. White Paper Prepared for the Forge Ahead e-Security Event 16/17 February 2006.

[39] Shareef, M., Jahankhani, H. and Mohammad, D. (2012) E-Government Stage Model: Based on Citizen-Centric Approach in Regional Government in Developing Countries. International Journal of Electronic Commerce Studies, 3, 145-164.

[40] Porter, M. (1985) Competitive Strategy: Techniques for Analyzing Industries and Competitors. Free Press, New York.

[41] Robert, D.A. and Jacob, U. (2000) Digital Government: The Next Step to Reengi- 
neering the Federal Government. Technology \& New Economy Project, Progressive Policy Institute, Washington DC.

[42] Holmes, D. (2001) E-Gov: E-Business Strategies for Government. Nicholas Brealey Publishers, London.

[43] Thompson, S.F. (2001) Committee on Governmental Affairs. In: United States Senate, Government at the Brink, Urgent Federal Government Management Problems Facing the Bush Administration, Vol. 1, Washington DC, 37. Dan Caterinicchia, “Tough times for 8(a)s", Federal Computer Week.

[44] Judi, H. (2001) Treasury CIO Promotes Expanded Fed Portal. Federal Computer Week, 14 .

[45] The Economist, 24 June 2000.

[46] Matthews, W. (2000) Setting a Course for E-Government. Federal Computer Week. http://www.fcw.com/fcw/articles/2000/1211/cov-egov-12-11-00.asp

[47] Kendall, K. and Kendall, J. (2008) Systems Analysis and Design. Pearson Education Inc., Upper Saddle.

[48] Kreps, D. and Richardson, H. (2007) IS Success and Failure-The Problem of Scale. The Political Quarterly, 78, 439-446. https://doi.org/10.1111/j.1467-923X.2007.00871.x

[49] Korpela, M., Soriyan, H.A., et al. (2000) Made-in-Nigeria Systems Development Methodologies: An Action Research Project in the Health Sector. In: Avgerou, C. and Walsham, G., Eds., Information Technology in Context. Studies from the Perspectives of Developing Countries, Ashgate Publishing Company, Burlington, 134153.

[50] Dovifat, A., Brueggemeier, M., et al. (2007) The Model of Micro-Political Arenas: A Framework to Understand the Innovation Process of E-Government-Projects. Information Polity: The International Journal of Government \& Democracy in the Information Age, 12, 127-138.

[51] Upton, D.M. and Staats, B.R. (2008) Radically Simple IT. Harvard Business Review, $86,118$.

[52] Brown, T. (2001) Modernization or Failure? IT Development Projects in the UK Public Sector. Financial Accountability and Management, 17, 363-381. https://doi.org/10.1111/1468-0408.00139

[53] Guy, P.B. (1996) The Future of Governing: Four Emerging Models. University of Kansas Press, Lawrence.

[54] Dale, W.J. and Khuong, M.V. (2016) The ICT Revolution, World Economic Growth, and Policy Issues. Telecommunications Policy, No. 40, 383-397.

[55] Microsoft (2015) Microsoft Partners with Kenya's ICTA to Strengthen ICT and Innovation. PC Tech Magazine, April 27. 
Submit or recommend next manuscript to SCIRP and we will provide best service for you:

Accepting pre-submission inquiries through Email, Facebook, LinkedIn, Twitter, etc. A wide selection of journals (inclusive of 9 subjects, more than 200 journals)

Providing 24-hour high-quality service

User-friendly online submission system

Fair and swift peer-review system

Efficient typesetting and proofreading procedure

Display of the result of downloads and visits, as well as the number of cited articles Maximum dissemination of your research work

Submit your manuscript at: http://papersubmission.scirp.org/

Or contact jis@scirp.org 